УДК 531.

DOI: https://doi.org/10.36910/6775-2313-5352-2019-14-10

Діхтієвський О.В., Квасніков В.П., д.Т.н., Возняковський А.О., к.т.н.

Національний авіаційний університет

\title{
ОЦНКА СИСТЕМАТИЧНОЇ ТА ВИПАДКОВОЇ СКЛАДОВИХ ПОХИБКИ ВИМІРЮВАННЯ ЦИЛІНДРИЧНИХ ЗУБЧАСТИХ КОЛІС
}

Для контролю всієї сукупності параметрів зубчастих коліс потрібне використання відразу иілої гами засобів вимірювальної техніки та комплексів. Багато з них морально застаріли, не автоматизовані, не мають виходу на комп'ютерні засоби і не забезпечують сучасного рівня точності, інформативності та швидкодії. На сьогоднішній день метрологічний контроль параметрів зубчастих коліс базується на великій кількості вимірювального обладнання. Всі вони мають обмежений діапазон вимірювальних параметрів, різну точність $i$ діапазон виміряних значень. Розглянуто комплекс робіт по створенню системи забезпечення єдності геометричних параметрів зубчастих передач. Це вимагає перегляду, систематизації та розробки методів та засобів метрологічного забезпечення. Розглянуто еталонну базу в області контролю евольвенти зубчастого колеса, яка вимагає ії створення на основі детального аналізу нових принщипів вимірювання, необхідності обтрунтування їх точності, розширення діапазону та діапазону вимірюваних параметрів. Тому в статті запропонована оцінка систематичної та випадкової складових похибки вимірювання циліндричних зубчастих коліс. Проведений аналіз похибок для реальних умов експлуатації на етапі попередніх досліджень, коли не відомий перелік складових основної похибки $i$ не проведена їх кількісна оиінка.

Ключові слова: шестерня, похибка, вимірювальний комплекс, швидкодія, діагностичний канал.

Для існуючих традиційних пристроїв [1] для вимірювань параметрів шестерні використовують як еталон реальний матеріальний об'єкт - виготовлену поверхню евольвенти [2], що має, хоча і невеликі, але реальні похибки - відхилення від теоретичної евольвенти. Як еталон використовується ідеальне уявлення у вигляді математичної моделі [3] 3 яким i порівнюється вимірюваний профіль шестерні.

Наявність сучасного комп'ютерного забезпечення [4] дозволяє здійснити автоматичну обробку результатів вимірювань, підвищити інформативність результатів за рахунок можливості графічного виведення інформації, значно підвищити точність результатів вимірювань за рахунок математичної компенсації похибок систематичних складових, а також зменшити випадкові похибки за рахунок статистичної обробки [5].

Bсе це створює передумови для розробки $\mathrm{i}$ впровадження на базі координатновимірювальних машин [6] сучасних прецизійних координатних методів і засобів вимірювань геометричних параметрів шестерні, а також їх метрологічного забезпечення.

В даний час ведеться виробництво нових модифікацій вітчизняних засобів вимірювань [7], систематично ввозяться з-за кордону, засновані на нових принципах, контрольно-вимірювальні прилади провідних зарубіжних виробників в області евольвентометрії, таких, як фірми Hofler, Klingelnberg, CarlZeiss, Mahr, Hommelverke.

Якість машин у великій мірі залежить від роботи зубчастих механізмів, які є найбільш поширені серед механічних передач завдяки своїм техніко-економічними показниками. Якість зубчастого колеса багато в чому визначається точністю цілого ряду параметрів, що залежать від технічного стану зубообробного обладнання, рівня технології, якості ріжучого інструменту i якості контрольно-вимірювальних операцій зубообробного виробництва.

Зубчасті колеса є найбільш масовими деталями, що застосовуються в машинобудуванні та приладобудуванні. Сьогодні в розпорядженні промисловість величезну кількість складних дорогих зубовимірювальних приладів, якими оснащені практично всі підприємства, що виробляють i контролюють зубчасті колеса. На сьогодні в Україні на промислових підприємствах експлуатується більше десятка тисяч засобів вимірювальної техніки всієї номенклатури геометричних параметрів.

Широке використання зубчастих коліс в багатьох галузях машинобудування та приладобудування ставить завдання розвитку метрологічного забезпечення їх виробництва. Це 
обумовлено вимогами підвищення точності, якості і конкурентоспроможності виробів, де вони використовуються.

Середнє арифметичне і вибіркова дисперсія можуть використовуватися в якості оцінок похибок вимірювання і при законах розподілу, що відрізняються від нормального. Однак зазвичай не вдається визначити закони розподілу цих одиничних оцінок і знайти їх довірчі інтервали. Щодо середнього арифметичного, то можна стверджувати, що вже при відносно невеликих $n$ (20-30) воно розподілено близько до нормального. Це дозволяє з достатньою для практики точністю використовувати квантилі нормального розподілу при оцінці інтервалу для середнього арифметичного. Аналогічно можна стверджувати, що при великій кількості вимірів $(n>100)$ для одномодальних аппроксимацій щільності розподілів можна використовувати нормальний розподіл при грубій оцінці інтервалу, який накриває істинне значення дисперсії випадкової похибки. Разом з тим для ряду розподілів зручно використовувати інші вибіркові характеристики.

Так, в разі рівномірного розподілу достатніми статистиками щодо математичного очікування і дисперсії є крайні члени варіаційного ряду. Для цього розподілу в якості оцінки математичного очікування необхідно брати центр $M$ розмаху, а замість вибіркового середнього квадратичного відхилення зручніше використовувати оцінку ширини розподілу $l$ :

$$
l=\frac{n+1}{2(n-1)}\left(x_{n}-x_{1}\right) .
$$

Дисперсія оцінок центру розмаху і його ширини:

$$
\begin{aligned}
D_{M} & =\frac{4 l^{2}}{2(n+1)(n+2)}, \\
D_{l} & =\frac{8 l^{2}}{(n+1)(n+2)} .
\end{aligned}
$$

Якщо оцінювати не середину розподілу і його ширину, а положення початкової $a$ i кінцевої $b$ точок розподілу, то оцінки і їх дисперсії відповідно:

$$
\begin{aligned}
a & =x_{1}-\frac{1}{n-1}\left(x_{n}-x_{1}\right), \\
b & =x_{n}+\frac{1}{n-1}\left(x_{n}-x_{1}\right), \\
D(a) & =D(b)=\frac{4 n}{\left(n^{2}-1\right)(n+2)} l^{2} .
\end{aligned}
$$

Центр розмаху доцільно використовувати при визначенні систематичної складової похибки вимірювання також в разі арксіносоїдального та інших розподілів. Для двухмодальних розподілів пропонується використовувати більш складну в обчислювальному відношенні оцінку. Для симетричних розподілів 3 позитивним ексцесом (Лапласа, узагальнене експоненціальне) ефективної оцінкою математичного очікування (при великих $n$ ) є медіана.

Для оцінки середнього квадратичного відхилення або дисперсії при невеликому $n$ зазвичай використовують статистики, засновані на розмахах, середньому розмаху, квазіразмахах і функціях від розмахів.

Таким чином, проблема визначення систематичної i оцінки випадкової складових похибок вимірювання може бути вирішена, якщо відомий вид закону розподілу і число дослідів $n$. Але в реальних ситуаціях припущення про те, що нам відомий вид закону розподілу, $\epsilon$ невиправданим. Це пояснюється як суттєвою залежністю статистичних властивостей похибки вимірювань від умов досліду, так і наявністю похибок вимірювання.

У зв'язку з цим велику цінність (особливо при автоматизованій обробці результатів вимірювань, коли людина не може оперативно втрутитися в процес обробки) мають оцінки робасні (стійкі) до виду розподілу тобто досить ефективні для широкого класу реальних розподілів. Природно, що подібні оцінки можуть бути менш ефективні, ніж оцінки, оптимальні для конкретного розподілу, Прикладом оцінки, стійкої до грубих похибок і виду симетричного розподілу з позитивним ексцесом, $\epsilon$ медіана. Робастною оцінкою середнього квадратичного відхилення $є$ медіана абсолютних відхилень. У той же час середнє арифметичне і дисперсія чутливі 
до грубих похибок. Правда, цензурування вибірки, використання квазірозмахів (підрозмахів) дозволяють збільшити стійкість оцінок до грубих похибок.

Загальним принципом конструювання робостних оцінок $є$ збільшення ваги тих елементів варіаційного ряду, які відомі та 3 найбільшою вірогідністю і в найбільшій мірі визначають оцінюваний параметр. А це означає, що для побудови хороших робостних оцінок все ж потрібна певна інформація про розподіл похибок вимірювань. Так, можна при оцінюванні математичного очікування симетричного розподілу 3 найбільшою вагою підсумовувати елементи, віддалені від математичного очікування на $1 / 4$ розмаху. У статистичній літературі наведені різні функції, що визначають ваги спостережень, оптимальні при відомому вигляді розподілу. Якщо інформація про розподіл оцінюваного параметра обмежена, то доцільно використовувати адаптивні процедури, наприклад, бівес-оцінку:

$$
x=\sum_{i=1}^{n} \frac{c_{j}}{\sum_{i=1}^{n} c_{i}} x_{j} .
$$

де $c_{j}-$ вагові коефіціснти.

$c_{j}=\begin{gathered}\left(1-u_{j}^{2}\right)^{2} \text { при } u_{j}^{2}<1 ; \\ 0 \text { при } u_{j}^{2} \geq 1, \\ x_{j}-x\end{gathered}$

де $u_{j}=\frac{x_{j}-x}{k S}-$ нормалізоване відхилення $x_{j}$ від оцінки математичного очікування $x ; S-$ рабостна оцінка середнього квадратичного відхилення. Зазвичай беруть медіану абсолютних відхилень або половину міжквартільного розмаху; $k$ - коефіцієнт, що дорівнює 6 або 9. 3 огляду на, що ваги в (7) вибираються як подвійне квадратичне зважування, тоді така оцінка називається «бівес» (біквадратна вага). Ця оцінка привласнює великі ваги результати вимірювань, близьким до оцінки $x$. По мірі зростання нормованого відхилення $u_{j}$ ваги зменшуються, а всі результати, що відхиляються від оцінки більше ніж на $k S$, просто відкидаються. Бівес визначається шляхом ітерацій, так як $x$ залежить від ваги $c_{j}$, а ваги - від $u_{j}$ яке, в свою чергу, визначається через $x$.

Інтервальна оцінка бівеса

$$
\left(\frac{t_{1-P_{d}} S_{x}}{2}<x<\frac{t_{1+P_{d}} S_{x}}{2}\right)=P_{d},
$$

де $S_{x}$ - оцінка середнього квадратичного відхилення бівеса, а квантиль розподілу Стьюдента береться для числа ступенів свободи $\vartheta=0,7(n-1)$. Дисперсія бівеса визначається

$$
S_{x}^{2}=\frac{n \sum_{j=1}^{n} c_{j}^{2}\left(x_{j}-x\right)^{2}}{\left(\sum_{j=1}^{n}\left(5 c_{j}-4 \sqrt{c_{j}}\right)\right)\left(\sum_{j=1}^{n}\left(5 c_{j}-4 \sqrt{c_{j}}\right)-1\right)} .
$$

При невеликих $n$ і невідомому розподілу похибок вимірювання для визначення границь довірчого інтервалу можна використовувати бутстреп-метод. Цей метод полягає у формуванні штучних вибірок, елементи яких вибираються випадковим чином з наявних експериментальних даних. Отримані таким чином вибірки застосовують потім для обчислення меж довірчого інтервалу. Існують і інші методи максимального використання всієї інформації, що міститься в малій вибірці.

При «ручній» обробці даних вимірювань зазвичай використовують для оцінки результату вимірювання медіани. Як зазначалося раніше, медіана-це вибіркова оцінка квантиль, якої відповідає рівню $P=0,5$. Будь-який елемент варіаційного ряду $x_{j} \epsilon$ вибірковою для ймовірності $P_{j}=j / n$.

Як відомо, ймовірність появи в $n$ незалежних випробуваннях рівно $i$ якихось «виділених» подій визначається формулою біноміального розподілу

$$
B(s, n, P)=C_{n}^{i} P^{i}(1-P)^{n-i},
$$

де $P$ - ймовірність появи «виділеної» події в одному спостереженні; $C_{n}^{i}-$ число поєднань з $n$ по $i$. Імовірність того, що в $n$ досвідах з'явиться не менше т виділених подій: 


$$
P(\mu \leq m, n, P)=\sum_{i=1}^{m} C_{n}^{i} P^{i}(1-P)^{n-i} .
$$

Вираз (11) затабуліровано для різних $P, n, m$. Імовірність події, що $l-$ й або $h-$ й елементи варіаційного ряду будуть не більше або не менш квантилі рівня $P$ визначається (11) при $m=l$ або $m=h$ відповідно. А ймовірність попадання квантилі рівня $P$ в інтервал, обмежений що $l-$ м та $h-$ м елементами варіаційного ряду, дорівнює

$$
P\left(x_{l} \leq x_{p} \leq x_{h}\right)=\sum_{i=1}^{m} C_{n}^{i} P^{i}(1-P)^{n-i} .
$$

Таким способом можна знайти довірчі інтервали для оцінок математичного очікування та середнього квадратичного відхилення, заснованих на порядкових статистиках: центрі розмаху, центрі міжквартільного розмаху, медіані, половині міжквартільного розмаху, розмаху і т.д.

Відомі й інші робастні оцінки зсуву і масштабу розподілу. Однак всі вони пов'язані 3 досить складними обчисленнями, ефективність більшості 3 них визначена тільки для деяких розподілів. Велика частина оцінок має асимптотичний характер, тобто справедлива при $n \rightarrow \infty$. Питання про те, як будуть вести себе ці оцінки в реальній ситуації, при кінцевому $n$ i конкретних видах розподілів, вимагають спеціальних досліджень.

Висновки. В даній роботі була проведена оцінка систематичних та випадкових складових похибки при вимірюванні зубчастих коліс. Встановлені методи та засоби вимірювання для оцінки математичного очікування та середнього квадратичного відхилення, заснованих на порядкових статистиках: центрі розмаху, центрі міжквартільного розмаху, медіані, половині міжквартільного розмаху, розмаху і т.д.

Інформаційні джерела

1. Локтев Д. А. Современные методы контроля качества цилиндрических зубчатых колес / Д. А. Локтев // Металлообработка. Оборудование и инструмент для профессионалов. - 2009. №4. - C. 6-11.

2. Тайц Б.А. Точность и контроль зубчатых колес / Б.А.Тайц. - М.: Машиностроение, 1972. $-369 \mathrm{c}$.

3. Сурков И.В. Метрологическое обеспечение процесса контроля зубчатых колес // Тезисы докладов международной научно-практической конференции / И.В. Сурков, Н.В. Сырейщикова.- Челябинск: Издательский центр ЮУрГУ, 2012. - Т. 1. - С. 225-227.

4. Марков Н.Н. Измерительные зубчатые колеса для комплексного контроля /Н.Н. Марков //Взаимозаменяемость и технические измерения в машиностроении. Межвузовский сборник № 2. - М.:Машгиз, 1960.-С. 286-312

5. Агапов, С.И. Прибор для оценки кинематической погрешности зуборезного оборудования в производственных условиях /С.И. Агапов // СТИН. -2006.-№ 2. С. 26-29.

6. Taylor B. N., Kuyatt Ch. E. Guidelines for Evaluatingand Expressing the Uncertainty of NIST Measurement Results.Washington, 1994.25p.

7. Агапов, С.И. Прибор для оценки кинематической погрешности зуборезного оборудования в производственных условиях /С.И. Агапов // СТИН. -2006.-№ 2. С. 26-29.

Дихтиевский А.В., Квасников В.П., Д.т.Н., Возняковский А.О., к.т.н.

Национальный авиационный университет

\section{ОЦЕНКА СИСТЕМАТИЧЕСКОЙ И СЛУЧАЙНОЙ СОСТАВЛЯЮЩЕЙ ПОГРЕШНОСТИ ИЗМЕРЕНИЯ ЦИЛИНДРИЧЕСКИХ ЗУБЧАТЫХ КОЛЕС}

Для контроля всей совокупности параметров зубчатых колес требуется использование сразу целой гаммы средств измерительной техники и комплексов. Многие из них морально устарели, не автоматизированы, не имеют выхода на компьютерные средства и не обеспечивают современного уровня точности, информативности и быстродействия. На сегодняшний день метрологический контроль параметров зубчатых колес базируется на большом количестве измерительного оборудования. Все они имеют ограниченный диапазон измерительных параметров, разную точность и диапазон измеренных значений. Рассмотрен комплекс работ по созданию системы обеспечения единства геометрических параметров 
зубчатых передач. Это требует пересмотра, систематизации и разработки методов и средств метрологического обеспечения. Рассмотрены эталонную базу в области контроля эвольвенты зубчатого колеса, которая требует ее создания на основе детального анализа новых принципов измерения, необходимости обоснования их точности, расширение диапазона u диапазона измеряемых параметров. Поэтому в статье предложена оиенка систематической и случайной составляющих погрешности измерения иилиндрических зубчатых колес. Проведенный анализ погрешностей для реальных условий эксплуатации на этапе предварительных исследований, когда не известен перечень составляющих основной погрешности и не проведена их количественная оценка.

Ключевые слова: шестерня, погрешность, измерительный комплекс, быстродействие, диагностический канал.

A.Dihtievskiy., V. Kvasnikov. Ph.D, A. Voznyakovskiy., PhD.

National Aviation University

\section{ESTIMATION OF THE SYSTEMATIC AND RANDOM COMPONENT OF THE MEASUREMENT ERROR OF CYLINDRICAL GEAR WHEELS}

In order to control the entire set of gear wheels parameters, it is necessary to use a whole range of measuring equipment and complexes at once. Many of them are outdated, unauthorized, have no access to computer tools and do not provide a modern level of accuracy, informationality and speed. To date, the metrological control of gear wheel parameters is based on a large number of measuring equipment. All of them have a limited range of measuring parameters, different accuracy and range of measured values. The complex of works on creation of a system of unity of geometric parameters of gear gears is considered. This requires revision, systematization and development of methods and means of metrological support. The reference base in the field of control of the gear draw gear is considered, which requires its creation on the basis of a detailed analysis of the new principles of measurement, the need to justify their accuracy, the expansion of the range and range of measured parameters. Therefore, the article proposes an estimation of the systematic and random components of the measurement error of cylindrical gear wheels. The analysis of errors for real operating conditions at the stage of previous studies, when the list of components of the basic error is not known and their quantitative assessment is not carried out.

Keywords: gear, error, measuring complex, speed, diagnostic channel. 